\title{
Argyrophil cells in normal, hyperplastic, and neoplastic endometrium
}

\author{
E SIVRIDIS, CH BUCKLEY, H FOX \\ From the Departments of Pathology, University of Manchester and St Mary's Hospital, Manchester
}

SUMMARY Scanty argyrophil cells are present in a substantial proportion of normal endometria, particularly during the secretory stage of the cycle. Argyrophil cells are also present in the various types of hyperplastic endometria and are found in more than half of endometrial adenocarcinomas. In some endometrial neoplasms they are present in abundance, but tumours rich in such cells do not have any features suggestive of a carcinoid tumour and are morphologically identical to adenocarcinomas of similar grade which are devoid of argyrophil cells. Endometrial adenocarcinomas containing argyrophil cells tend to be well differentiated and tend not to invade deeply into the myometrium. It is suggested that Müllerian epithelial stem cells possess a potentiality for differentiation into APUD cells.

Fox et al ${ }^{1}$ were unable to show any argyrophil cells in normal endometrium using a Bodian stain. Nevertheless, there have been a number of reports recently of adenocarcinomas of the endometrium containing argyrophil cells, ${ }^{2-4}$ and, indeed, it has been claimed that as many as $22 \%$ of endometrial adenocarcinomas contain argyrophil cells. ${ }^{4} \mathrm{We}$ report here a re-evaluation of the presence or otherwise of argyrophil cells in normal endometrium and a study of their occurrence in hyperplastic and neoplastic endometria.

\section{Material and methods}

The material used for this study was drawn from the files of the Department of Pathology, St Mary's Hospital, Manchester. The tissues were all from specimens obtained at operation and had been routinely fixed in $10 \%$ formol-saline. The original haematoxylin and eosin stained sections consisted of 80 normal endometria from various stages of the menstrual cycle, 72 cases of endometrial hyperplasia, and 74 endometrial adenocarcinomas. The endometrial neoplasms were typed in accordance with the classification of Hendrickson and Kempson $^{5}$ and graded histologically in terms of the FIGO grading system as G1 (adenomatoid), G2 (partly adenomatoid and partly solid), and G3 (solid); their depth of invasion into the myometrium was recorded in terms of invasion of inner, middle, and

Accepted for publication 30 November 1983 outer thirds. The hyperplastic endometria were classified along the lines suggested by Fox and Buckley: ${ }^{6}$ in this classification simple hyperplasia corresponds with cystic glandular hyperplasia; simple glandular hyperplasia is equivalent to hyperplasia with architectural atypia; while intraendometrial neoplasia grades I to III (IEN I-III) encompasses all forms of hyperplasia with cytological atypia and intraendometrial adenocarcinoma.

Selected blocks from each case were recut and sections stained by the Grimelius technique; ${ }^{7}$ in all staining runs sections of normal small intestine were used as positive controls.

The number of argyrophilic cells in a section was counted in an arbitrary, but nevertheless reproducible, manner:

$+=$ only one or two argyrophilic cells present in the entire section

$++=$ occasional scattered argyrophilic cells present, but no more than 10 in the entire section $+++=$ more than 10 argyrophilic cells present, but these were scattered and did not form the predominant cell type in any area

$++++=$ numerous argyrophilic cells present and in at least one area constituted the predominant cell type.

\section{Results}

These are shown in Tables 1-3. Argyrophilic cells, albeit usually in scanty numbers, were present in the normal endometrium, more commonly in the sec- 


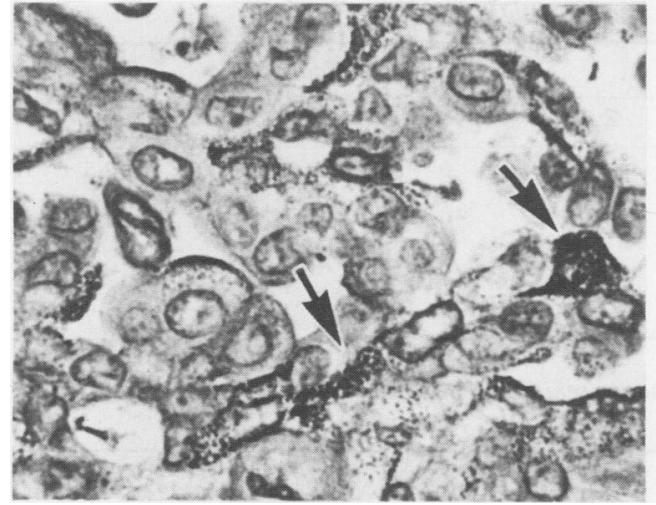

Argyrophil cells (arrowed) in an endometrial adenocarcinoma. Grimelius stain $\times 800$.

retory phase than in the proliferative phase of the cycle. Such cells were present in glandular epithelium in both the zona basalis and the zona functionalis.

Argyrophil cells were present in more than half of the invasive endometrial neoplasms and were present both in glandular and surface epithelium (Figure). The incidence of positive argyrophilia was the same in those tumours arising from an otherwise atrophic endometrium and those developing against a background of intraendometrial neoplasia, and in no case did any of the neoplasms containing argyrophil cells have a morphological appearance suggestive of a carcinoid tumour. In fact there were no morphological differences apparent between adenocarcinomas containing argyrophil cells and those of comparable grade lacking such cells.

The cells staining positively with the Grimelius technique were usually triangular or flask shaped with a broad base in apposition to the basement membrane of the epithelium. The positively staining cytoplasmic granules were brown or black and uniformly small and round; they tended to be predominantly supranuclear, but some cells showed an infranuclear localisation and in a few the granules were dispersed throughout the entire cytoplasm of the cell. The argyrophilic cells in normal and hyperplastic endometria tended to be smaller and less densely granulated than those in endometrial neoplasms.

\section{Discussion}

In this study argyrophil cells were found in normal, hyperplastic, and neoplastic endometria. In the normal endometrium such cells were more commonly present in the secretory phase than in the proliferative phase and this could be indicative of a maturational process. It is of interest, however, that argyrophil cells were present in cases of both simple endometrial hyperplasia and simple glandular hyperplasia in roughly the same proportions as in normal proliferative endometrium. This supports a previous suggestion that such lesions represent a distortion of the normal proliferative phase rather than a "preneoplastic" abnormality. ${ }^{6}$

The finding that more than half of the endometrial adenocarcinomas contained argyrophil cells, often in abundance, was surprising; when we started this study we had been sceptical about previous reports of argyrophilia in endometrial neoplasms. It is important to emphasise, however, that these were adenocarcinomas containing argyrophil cells rather than true argyrophil cell tumours, for none showed any morphological features suggestive of a carcinoid tumour. Indeed, a definite carcinoid tumour of the endometrium has not been reported; this contrasts with the uterine cervix, where typical carcinoid tumours have been fully described and illustrated. ${ }^{89}$

In this study adenocarcinomas of the endometrium containing argyrophil cells tended to be well differentiated and less invasive than adenocarcinomas devoid of argyrophil cells; beyond this, however, the finding of argyrophil cells in an endometrial adenocarcinoma appeared to be of no particular relevance. Our results in this respect are somewhat at variance with those of Ueda et al: ${ }^{4}$ in their series of nine endometrial adenocarcinomas containing argyrophil cells only four were well differentiated and only five were stage 1 at the time of initial diagnosis.

There is little doubt that the argyrophilic cells in an endometrial adenocarcinoma are true APUD cells for electron microscopy shows that they contain neurosecretory granules, ${ }^{4}$ calcitonin is often shown by immunohistological techniques, ${ }^{10}$ and they are able to take up and decarboxylate amine precursors. ${ }^{11-13}$ The mere presence of argyrophil cells in an adenocarcinoma does not, however, merit such neoplasms being regarded as neuroendocrine tumours for such cells have been described in gastric adenocarcinomas, ${ }^{14-16}$ ductal and lobular carcinomas of the breast, ${ }^{1718}$ colonic adenocarcinomas, ${ }^{1519}$ prostatic carcinomas, ${ }^{2021}$ and Brenner tumours of the ovary. ${ }^{21}$ In our present state of knowledge it is difficult to propose any unifying hypothesis to explain the occurrence of these cells in such a wide range of neoplasms. It is unlikely that non-neoplastic argyrophil cells are accidentally included within a proliferating neoplasm for this would explain neither their occurrence in mammary tumours (argyrophil cells being absent from the normal breast ${ }^{21}$ ) nor the higher incidence of argyrophil cells in neoplastic compared with normal 
Table 1 Prevalence of argyrophilic cells in normal, hyperplastic, and neoplastic endometria

\begin{tabular}{|c|c|c|c|c|c|c|c|}
\hline \multirow[t]{2}{*}{ Tissue } & \multirow{2}{*}{$\begin{array}{l}\text { Total } \\
\text { no }\end{array}$} & \multicolumn{4}{|c|}{ Argyrophil cells } & \multirow{2}{*}{$\begin{array}{l}\text { Total } \\
\text { positive }\end{array}$} & \multirow[t]{2}{*}{$\%$ positive } \\
\hline & & + & ++ & +++ & ++++ & & \\
\hline $\begin{array}{l}\text { Normal proliferative endometrium } \\
\text { Normal secretory endometrium } \\
\text { Simple endometrial hyperplasia } \\
\text { Simple glandular hyperplasia } \\
\text { IEN grade I } \\
\text { IEN grade II-III } \\
\text { Invasive endometrial adenocarcinoma }\end{array}$ & $\begin{array}{l}40 \\
40 \\
22 \\
25 \\
10 \\
15 \\
74\end{array}$ & $\begin{array}{l}0 \\
4 \\
3 \\
2 \\
0 \\
1 \\
0\end{array}$ & $\begin{array}{l}4 \\
7 \\
0 \\
1 \\
1 \\
0 \\
7\end{array}$ & $\begin{array}{r}1 \\
3 \\
0 \\
0 \\
0 \\
2 \\
13\end{array}$ & $\begin{array}{r}0 \\
0 \\
0 \\
0 \\
0 \\
1 \\
19\end{array}$ & $\begin{array}{r}5 \\
14 \\
3 \\
3 \\
1 \\
4 \\
39\end{array}$ & $\begin{array}{l}12 \cdot 5 \\
35 \\
13 \cdot 6 \\
12 \\
10 \\
26 \cdot 6 \\
52 \cdot 7\end{array}$ \\
\hline
\end{tabular}

Table 2 Prevalence of argyrophilic cells in endometrial carcinomas in relation to the histological type and grade of tumour differentiation

\begin{tabular}{|c|c|c|c|c|c|c|c|}
\hline \multirow[t]{2}{*}{ Endometrial tumour } & \multirow{2}{*}{$\begin{array}{l}\text { Total } \\
\text { no }\end{array}$} & \multicolumn{4}{|c|}{ Argyrophil cells } & \multirow{2}{*}{$\begin{array}{l}\text { Total } \\
\text { positive }\end{array}$} & \multirow[t]{2}{*}{$\%$ positive } \\
\hline & & + & ++ & ++ & $++t$ & & \\
\hline $\begin{array}{l}\text { Endometrioid adenocarcinon } \\
\text { G1 } \\
\text { G2 } \\
\text { G3 } \\
\text { Papillary carcinoma } \\
\text { Clear cell carcinoma } \\
\text { Adenosquamous carcinoma } \\
\text { Total } \\
\%\end{array}$ & $\begin{array}{r}50 \\
7 \\
7 \\
6 \\
2 \\
2 \\
74\end{array}$ & & $\begin{array}{l}5 \\
2 \\
0 \\
0 \\
0 \\
0 \\
7 \\
9 \cdot 5\end{array}$ & $\begin{array}{c}9 \\
0 \\
1 \\
2 \\
1 \\
0 \\
13 \\
17 \cdot 6\end{array}$ & $\begin{array}{r}14 \\
0 \\
1 \\
3 \\
0 \\
1 \\
19 \\
25 \cdot 6\end{array}$ & $\begin{array}{r}28 \\
2 \\
2 \\
5 \\
1 \\
1 \\
39\end{array}$ & $\begin{array}{l}56 \\
28 \cdot 5 \\
28 \cdot 5 \\
83 \cdot 3 \\
- \\
- \\
52 \cdot 7\end{array}$ \\
\hline
\end{tabular}

Table 3 Incidence of positive Grimelius staining in 74 endometrial tumours in relation to the depth of myometrial invasion

\begin{tabular}{|c|c|c|c|c|c|c|c|}
\hline \multirow{2}{*}{$\begin{array}{l}\text { Depth of } \\
\text { myometrial invasion }\end{array}$} & \multirow{2}{*}{$\begin{array}{l}\text { Total } \\
\text { no }\end{array}$} & \multicolumn{4}{|c|}{ Argyrophil cells } & \multirow{2}{*}{$\begin{array}{l}\text { Total } \\
\text { positive }\end{array}$} & \multirow[t]{2}{*}{$\%$ positive } \\
\hline & & + & ++ & +++ & ++++ & & \\
\hline $\begin{array}{l}\text { Up to inner third } \\
\text { Inner two thirds } \\
\text { Outer third }\end{array}$ & $\begin{array}{l}29 \\
26 \\
19\end{array}$ & & $\begin{array}{l}3 \\
1 \\
3\end{array}$ & $\begin{array}{l}6 \\
4 \\
3\end{array}$ & $\begin{array}{l}7 \\
9 \\
3\end{array}$ & $\begin{array}{r}16 \\
14 \\
9\end{array}$ & $\begin{array}{l}41 \\
35 \cdot 9 \\
23\end{array}$ \\
\hline
\end{tabular}

or hyperplastic endometria. It is not now believed that all APUD cells are of neuroectodermal origin; within endodermal tissue it appears that both epithelial cells and argyrophil cells originate from a common stem cell. ${ }^{22}$ It therefore seems probable that within epithelia of Müllerian origin there is a similar possibility of differentiation of stem cells along an APUD pathway.

\section{Addendum}

Since this paper was submitted for publication Bannatyne et $a l^{23}$ have described the finding of argyrophil cells in $68 \%$ of a series of 25 endometrial adenocarcinomas. The presence of such cells was of no clinicopathological importance.

\section{References}

' Fox H, Kazzaz B, Langley FA. Argyrophil and argentaffin cells in the normal female genital tract and in ovarian mucinous cysts. J Pathol Bacteriol 1964;88:479-88.

${ }^{2}$ Ueda G, Sato Y, Yamasaki M, et al. Argyrophil cell adenocar- cinoma of the endometrium. Acta Obstet Gynaecol Jap 1977;9:1167-8.

${ }^{3}$ Ueda G, Sato Y, Yamasaki M, et al. Argyrophil cell adenocarcinoma of the endometrium. Gynecol Oncol 1978;6:467-73.

${ }^{4}$ Ueda G, Yamasaki M, Inoue M, Kurachi K. A clinicopathologic study of endometrial carcinomas with argyrophil cells. Gynecol Oncol 1979;7:223-32.

${ }^{5}$ Hendrickson MR, Kempson RL. Surgical pathology of the uterine corpus. London: Saunders, 1980.

6 Fox $\mathrm{H}$, Buckley $\mathrm{CH}$. The endometrial hyperplasias and their relationship to endometrial neoplasia. Histopathology 1982;6:493-510.

7 Grimelius L. A silver nitrate stain for $\alpha_{2}$ cells in human pancreatic islets. Acta Soc Med Uppsala 1968;73:243-70.

${ }^{8}$ Tateishi R, Wada A, Hayakawa K, Hongo J, Ishii S, Terakawa N. Argyrophil cell carcinomas (apudomas) of the uterine cervix: light and electron microscopic observations of 5 cases. Virchows Arch (Pathol Anat) 1975;366:257-74.

${ }^{9}$ Albores-Saavedra J, Rodriguez-Martinez HA, LarrazaHernandez O. Carcinoid tumors of the cervix. Pathol Annu 1979;14:273-91.

${ }^{10}$ Ueda G, Yamasaki M, Inoue M, Tanaka Y, Kurachi K. Immunohistological demonstration of calcitonin in endometrial carcinomas with and without argyrophil cells. Acta Obstet Gynaec Jap 1980;32:960-64.

"Inoue M, Ueda G, Yamasaki M, et al. Capacity for amineprecursor uptake and decarboxylation of argyrophil cell adenocarcinoma of the endometrium. Gynecol Oncol 
1982;13:19-25.

'2 Inoue M, Ueda G, Yamasaki M, Tanaka Y, Hiramatsu K, Kurachi K. An in vitro incubation study of amine-precursor uptake and decarboxylation in the cytoplasm of argyrophil cell adenocarcinoma of the endometrium. Gynecol Oncol 1982;14:75-9.

${ }^{13}$ Inoue M, Ueda G, Yamasaki M, et al. Endometrial argyrophil cell adenocarcinoma with indole- or catecholamine precursor uptake and decarboxylation. Int $J$ Gynecol Pathol 1982;1:47-58.

${ }^{14}$ Azzopardi JG, Pollock DJ. Argentaffin and argyrophil cells in gastric carcinoma. J Pathol Bacteriol 1963;86:443-51.

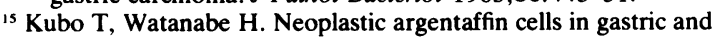
intestinal carcinomas. Cancer 1971;27:447-54.

${ }^{16}$ Proks C, Veit V. Gastric carcinomas with argyrophil and argentaffin cells. Virchows Arch (Pathol Anat) 1982;395:201-6.

${ }^{17}$ Partanen S, Syrjanen K. Argyrophil cells in carcinoma of the female breast. Virchows Arch (Pathol Anat) 1981;391:45-51.

${ }^{18}$ Fetissof F, Dubois MP, Arbeille-Brassart B, Lansac J, Jobard J. Argyrophilic cells in mammary carcinoma. Hum Pathol 1983;14:127-34.
${ }^{19}$ Gibbs NM. Incidence and significance of argentaffin and Paneth cells in some tumours of the large intestine. J Clin Pathol 1967;20:826-31.

${ }^{20}$ Azzopardi JG, Evans DJ. Argentaffin cells in prostatic carcinoma: differentiation from lipofuscin and melanin in prostatic epithelium. J Pathol 1971;104:247-51.

${ }^{21}$ Fetissof F, Dubois MP, Arbeille-Brassart B, Lanson Y, Boivin F, Jobaro $P$. Endocrine cells in the prostate gland, urothelium and Brenner tumors: immunohistological and ultrastructural studies. Virchows Archiv (Cell Pathol) 1983;42:53-64.

${ }^{22}$ Sidhu GS. The endodermal origin of digestive and respiratory tract APUD cells: histopathologic evidence and a review of the literature. Am J Pathol 1979;96:5-20.

${ }^{23}$ Bannatyne P, Russell P, Wills EJ. Argyrophilia and endometrial carcinoma. Int J Gynecol Pathol 1983;2;235-54.

Requests for reprints to: Professor H Fox, Department of Pathology, University of Manchester, Stopford Building, Oxford Road, Manchester M13 9PT, England. 